\title{
CORRESPONDENCE
}

\section{Measurement of thecal spacing in graptolites}

SIR - Many graptolite species and subspecies have traditionally been distinguished in part by variations in the rhabdosome width and thecal spacing. In tectonically deformed rocks these parameters may be markedly altered, and any classification based largely on such measurements will then be unworkable. Even in tectonically undeformed rocks, rhabdosome dorso-ventral width variations may sometimes be considerable, owing to differences in compaction and differential flattening. The thecal spacing is, however, largely independent of diagenetic flattening, and is thus potentially very important in distinguishing between taxa.

There has been considerable discussion in the literature as to the best method for measuring thecal spacing (e.g. Rickards, 1970; Bjerreskov, 1975). Traditionally this has been done by laying a scale against the specimen and counting the number of thecae in one inch or one centimetre; generally only distal values being recorded. Bjerreskov (1975) followed this method when she quoted the number of thecae in the proximal and distal $10 \mathrm{~mm}$, except when the rhabdosome was strongly curved or short, when she gave the number of thecae in 5 or $2.5 \mathrm{~mm}$.

This method has three disadvantages. Thecal spacing normally varies considerably in the proximal end, but is more constant distally. Averaging over the proximal $10 \mathrm{~mm}$ loses much of the precision that could be gained by measuring just one or two thecae. Important differences in thecal spacing at the proximal end would be lost. Secondly, estimating the number of thecae in a given length is not as accurate as precise measurement of the distance between corresponding points on two thecae a specified number of thecae apart. Thirdly, measuring thecae per unit length results in units of 1/length. Comparative astogenetic sequences using scatter diagrams of one parameter against another are more logical using the same dimensions, for example length $\mathrm{v}$. length, rather than $1 /$ length $\mathrm{v}$. length, as would result from a plot of thecae in $10 \mathrm{~mm}$ against dorso-ventral width. It gives a simpler plot and is more easily interpreted.

Packham (1962) and Rickards $(1965,1970)$ attempted to obtain more accurate proximal values by measuring the spacing over a small number of thecae, and then by extrapolation, quoted the number of thecae in $10 \mathrm{~mm}$. Bjerreskov (1975) rejected this because it gave 'strongly biased averages'. While it is true that values obtained by the Packham and Rickards method cannot be compared with Bjerreskov's measurements, they can provide more detailed information if the position of the thecae measured is recorded. The value obtained from th $1-$ th 2 is likely to be significantly different from that between th3-th5. This is clearly illustrated in Figure 1, where for a specimen of Monograptus marri Perner, the thecal spacing over the proximal $10 \mathrm{~mm}$ is 11 (traditional method), whereas extrapolating the th1-th3 spacing gives 13.2 thecae in $10 \mathrm{~mm}$, th4-th6 gives 11.4 thecae in $10 \mathrm{~mm}$, and th9-th 11 gives 10.2 thecae in $10 \mathrm{~mm}$ (cf. method of Packham and Rickards). Clearly, an alternative, accurately defined method is required.

The measurement introduced herein is called the 'Two Thecae Repeat Distance' (2TRD) and is defined for th $n$ as the distance in millimetres between equivalent points (for example, the junction of the free ventral wall and the interthecal septum) on thn-1 and thn+1. The distance is measured over two thecae to average out some of the minor differences in diagenetic flattening and inhomogeneous deformation, without sacrificing critical resolution in the proximal part of the rhabdosome. Care must be taken to avoid malformed or poorly preserved thecae. Precisely defined values can then be simply quoted, for example 2 TRD (th2) $=1.52 \mathrm{~mm}$. See Figure 1 for illustration of measurements.

The 'Two Thecae Repeat Distance' can be plotted directly against the dorso-ventral width, to aid accurate distinction of species. Rickards and Palmer (1977) used a related plot of dorso-ventral width against distance from the sicula aperture in their investigations of certain early Ludlow monograptids, either for each successive theca (fig. 6A, B) or at th1, 5, 10, 15, 20 and 25 (fig. 6C). The 2TRD method is not only quicker and simpler, but better illustrates the thecal variation within a given species, as it compares individual thecae, rather than the sum of individual thecae. It can also be applied in some cases where the proximal end is missing.

Geol. Mag. 120 (6), 1983, pp. 635-638. Printed in Great Britain. 


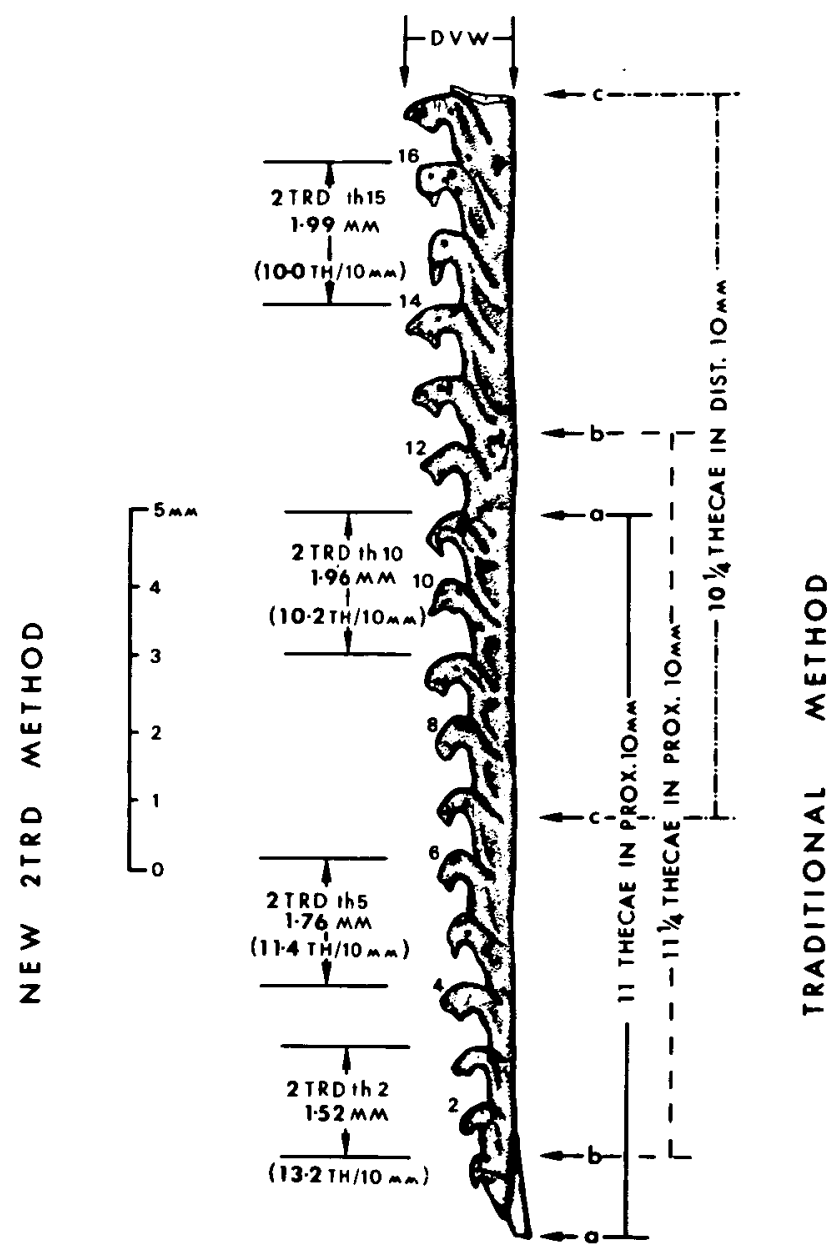

Figure 1. Monograptus marri Perner (PMO 97944, crispus Zone, road cutting near Feldberg, Hadeland, southern Norway). Diagram illustrating the measurement of 2TRD at th2, 5, 10 and 15, and dorso-ventral width at th17. The values are also expressed as thecae in $10 \mathrm{~mm}$ to aid comparison with results obtained by the traditional method of measuring the number of thecae in the proximal $10 \mathrm{~mm}$ ( $\mathrm{a}$ - including sicula, $\mathrm{b}$ - excluding sicula) and distal $10 \mathrm{~mm}$ (c). The 2TRD method demonstrates important detailed variations that are masked by the traditional method.

Cooper and Fortey (1982) developed the 'stipe expansion' diagram, a plot of dorso-ventral width against the thecal number, and convincingly demonstrated its use in distinguishing closely related species in various groups of Ordovician graptolites. However, as they themselves stressed, this method includes no measure of thecal density, and two species with very different thecal spacings could give identical expansion diagrams. Their method also depends upon the presence of a sufficient number of specimens with the proximal end preserved.

In Figure 2 the 'Two Thecae Repeat Distance' is plotted against the dorso-ventral width for th2, th5, th10 and thdistal in a sample of Climacograptus transgrediens Wærn from the Llandovery of Ormøya, near Oslo, Norway. Significant differences can be seen between the 2TRD at th2 and th5. The standard deviations of the 2TRDs and the dorso-ventral widths are also plotted as $1 \sigma$ on either side of the mean. These have been calculated independently for each variable, although as much of it is due to tectonic compression spreading the points out along NW-SE lines, more sophisticated techniques could be used. Where it is advantageous to emphasise the measurements of individual 


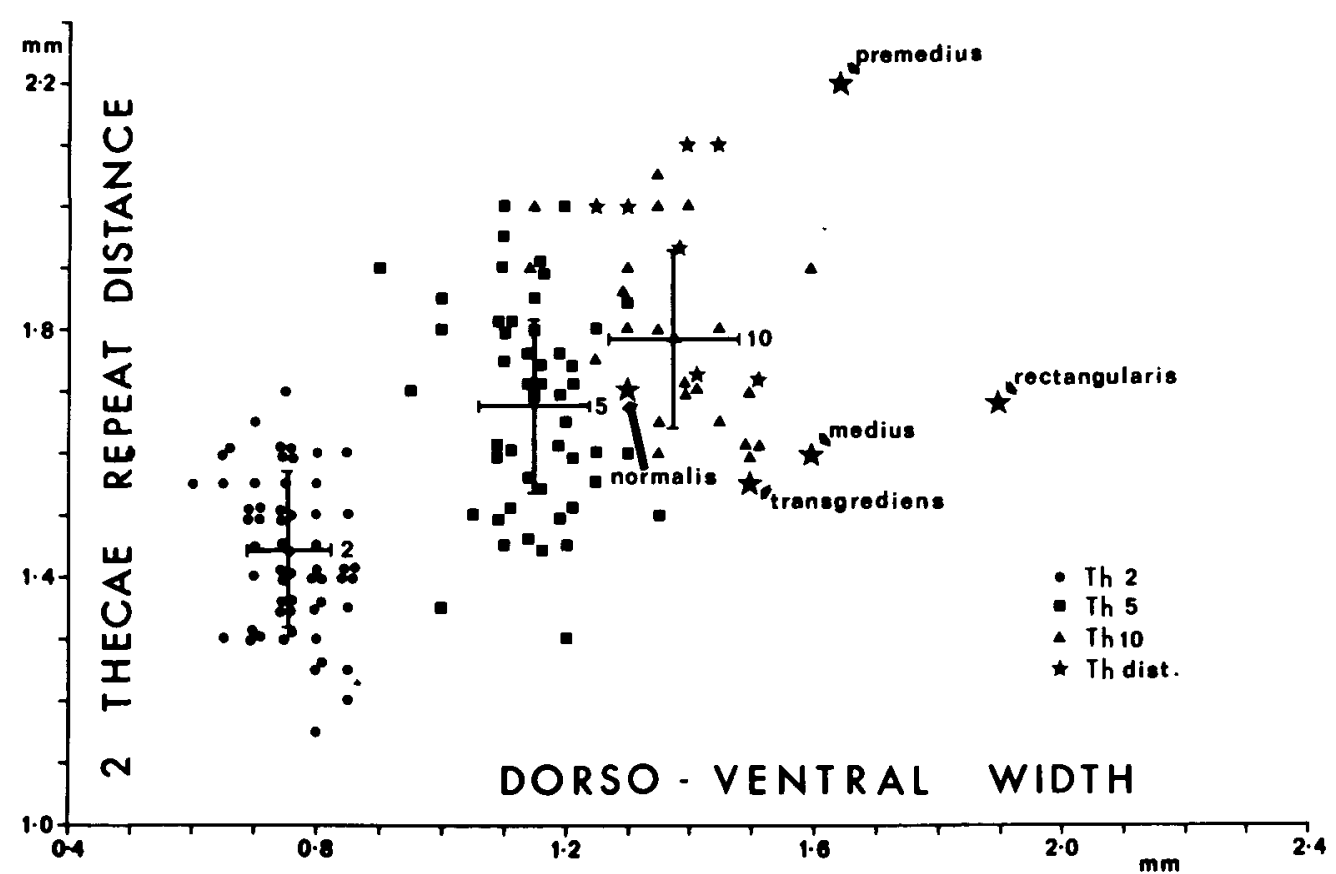

Figure 2. Climacograptus transgrediens Wærn from the Lower Llandovery of Ormøya, near Oslo. (For full details, see Howe, in prep.) Graph showing the variation in 2TRD against dorso-ventral width at th2, 5, 10 and dist. The mean values and standard deviations are shown for th2, 5 and 10. Equivalent distal values for some other climacograptids are also plotted (from Warn, 1948); no comparable proximal values have yet been published.

rhabdosomes, tie lines may be used to connect the respective plotted points. In a biserial rhabdosome, the 2TRDs are measured along the primary series; thus between the apertures of th $4^{1}-$ th $^{1}$ for 2 TRD th5, and th $9^{1}-$ th $11^{1}$ for 2TRD th 10 .

Distal values for $C$. premedius, normalis, medius, rectangularis and transgrediens from Sweden (Warn, 1948) are also plotted for comparison in Figure 2. As more detailed information on the 2TRD ranges in different species becomes available, the importance of such plots will increase. Use of the abbreviation '2TRD' should be encouraged, as it is short, but precisely defined.

\section{References}

Bjerreskov, M. 1975. Llandoverian and Wenlockian graptolites from Bornholm. Fossils and Strata 8, 93pp.

Cooper, R. A. \& Fortey, R. A. 1982. The Ordovician Graptolites of Spitsbergen. Bull. Br. Mus. nat. Hist., Ser. Geol. 36, (3), 157-302, pl. 1-6.

Howe, M. P. A. (in prep.). Lower Llandovery graptolites and the base of the Silurian in the Oslo Region.

Packham, G. H. 1962. Some diplograptids from the British Lower Silurian. Palaeontology 5, 498-526, pl. 71,72 .

Rickards, R. B. 1965. New Silurian graptolites from the Howgill Fells (Northern England). Palaeontology 8, 247-71, pl. 29-31.

Rickards, R. B. 1970. The Llandovery (Silurian) graptolites of the Howgill Fells, Northern England. Palaeontogr. Soc. [Monogr.], 108pp., 8 plates.

Rickards, R. B. \& Palmer, D. C. 1977. Early Ludlow monograptids with Devonian morphological affinities. Lethaia 10, 59-70. 
Wærn, B. 1948. The Silurian Strata of the Kullatorp Core. pp. 433-74, pl. 26, in Wærn, B., Thorslund, P., Henningsmoen, G. \& Säve-Söderbergh, G. Deep boring through Ordovician and Silurian strata at Kinnekulle, Vestergötland. Bull. geol. Instn Univ. Upsala 32, 337-474, pl. 20-6.

\section{Sedgwick Museum}

M. P. A. HOWE

Department of Earth Sciences

Downing Street

Cambridge

CB2 3EQ

20th February 1983 